\title{
The Influence of Civil Servant Competence and Bureaucratic Reform on Organizational Performance at the Government Offices in Cianjur
}

\author{
Benyamin Harits ${ }^{1}$ and Tombak Gapura Bhagya ${ }^{2}$
}

\author{
${ }^{1}$ Faculty of Social and Political Sciences, Pasundan University, Bandung, Indonesia \\ ${ }^{2}$ Faculty of Technic, Insan Cendekia Mandiri University, Bandung, Indonesia \\ Corresponding author: benharits15@gmail.coml'tombak.gapura.bhagya1@gmail.com²
}

\begin{abstract}
This journal provides an analysis of the effect of three variables applied to the offices in Cianjur. Civil servant competence variables and bureaucratic reform variables are used as independent variables and organizational performance variables are used as dependent variables. Structural Equation Mathematics (SEM) is used as a tool to measure how independent variables can be explained by dependent variables. At the offices in Cianjur, The employees became the sample in this study through a structured division, based on weighting the number of employees in each service. Lisrel Software is used as a tool to process the data obtained for generating quantitative values for further analysis. The results showed that the competence of the civil servant and bureaucratic reform affected the organizational performance of the offices in Cianjur.
\end{abstract}

Keywords: civil servant competence, bureaucratic reform, organizationa performance, SEM

\section{INTRODUCTION}

Indonesia is currently facing the Covid 19 Pandemic, so it is necessary to carry out substantive arrangements in various dimensions of life, especially regarding the arrangement and improvement in the field of government, both at the central and regional levels. These rearrangements and improvements were deliberately carried out to anticipate and overcome various negative impacts due to ineffective and inefficient governance during the Covid 19 pandemic [1]-[2]. The emergence of economic and social problems which later turned into a political crisis further strengthens the argument that government administration is necessary for structuring and reforming substantively and comprehensively. These various steps for structuring and reforming the government have become known as bureaucratic reform. According to Wibawa (2005), bureaucratic reform is a movement to change the system and behavior of bureaucrats because the conditions are no longer suitable and are not following current reality [3]. This opinion showed that bureaucratic reform arises because of the gap between the demands of society and the capabilities of the bureaucrats. This results in bureaucrats no longer being an option for the public in entrusting their hopes for every aspiration they want.
With restrictions on employees entering the office during the Covid 19 pandemic, local governments need to improve employee performance through strengthening and increasing the competence of the civil servant. The problem of competence has become a classic problem for bureaucrats, not only during the Covid 19 pandemic but in normal conditions, the problem of civil servant competence is always in the public spotlight [4]-[5].

The research related to bureaucratic reform was carried out by Hendroyuwono regarding Bureaucratic Reform in Public Organizations: The Role of External Environment Complexity, Strategic Capabilities, Change Capabilities and Leadership Styles in Driving Performance Improvement (Case study: bureaucratic reform at the Directorate General of Taxes, Ministry of Finance of the Republic of Indonesia) [6]. Preliminary research results reveal that the quality of the tax service system and the enforcement of tax regulations have not been effective. This problem has implications for an inefficient tax management system [7]. As a result, the tax revenue target has not been achieved optimally. The preliminary findings illustrate that public services are given by the city government has not been effective. This is reflected in the low initiative of the officials in responding to every 
complaint submitted by the community, frequent delays for reasons that are unclear and irrational, too many forms to be filled in when dealing with some permits, and the attitude of the officers who are not friendly. These preliminary findings are inherent with the ineffective implementation of bureaucratic reform. According to Mahmudi, public sector management must always think about how to continue improving apartment competence so that bureaucrats can increase the performance value of public organizations [8]. This view shows that continuing to improve performance in the public sector is essential. Civil servant competency improvement should be directed towards efforts to build the capacity of the civil servant by the main duties and functions of the civil servant as public servants. The urgency to improve the performance of government organizations is driven by the development and acceleration as well as the increasingly high dynamics of community life [9]. The acceleration of the increase in science and technology that occurs in society is also one of the driving factors for the strengthening of public demands for the performance displayed by government organizations. This phenomenon, empirically, then causes a shift in the mindset and lifestyle of the community that leads to a climate that is completely competitive, fast, and efficient, even pragmatic.

Related to competency research, many researchers have conducted research based on competencies such as Imatama researched the Effect of Competence and Motivation on Employee Performance at PDAM Tirtanadi, Padang Bulan Branch, Medan. This study aims to analyze the extent to which competencies consisting of knowledge, skills, and attitudes as well as work motivation affect the performance of the employees of PDAM Tirtana at Padang Bulan Branch [10]. Zaim et al (2013) and $\mathrm{Xu}$ and Ye (2014) conducted a study on the effect of individual competence on performance in several organizations in Turkey. This study aims to analyze the effect of individual competence on the performance of the service industry in Turkey. This research is a study by conducting a survey that aimed at companies in the service sector in Turkey with many questionnaires distributed to 3000 employees in 30 companies. The total number of questionnaires returned was 2,679 and considered to represent a response rate of 89 percent of the total population [11], [12].

Based on empirical facts, the performance of government organizations to date has not shown optimal results. This condition can be observed from various phenomena, such as public services that are still convoluted, the uncertainty of time in providing services, the emergence of uncertainty in service costs, and the low commitment of officials in carrying out their duties, which is a reflection that the performance of the government as an institution has not yet shown optimal results. The implication is that many people complain about the performance of the services provided by the government. This predisposition has occured not only in government institutions at the central level but has also in the regional government, including within Cianjur Government.

Table 1. Organizational Performance Reports of agencies in Cianjur

\begin{tabular}{|c|c|c|c|}
\hline Activities & Target & Reality & Information \\
\hline $\begin{array}{l}\text { Negligence in } \\
\text { maintaining irrigation networks. }\end{array}$ & $\begin{array}{l}\text { No irrigation network } \\
\text { was damaged. }\end{array}$ & $\begin{array}{l}\text { Irrigation network } \\
\text { conditions that severely } \\
\text { damaged about } 66.67 \% \text {, } \\
14.28 \% \text { were lightly } \\
\text { damaged, and only } \\
19.04 \% \text { were not } \\
\text { damaged. }\end{array}$ & $\begin{array}{l}\text { Weak maintenance of } \\
\text { irrigation networks, } \\
\text { which often results in } \\
\text { crop failures. }\end{array}$ \\
\hline $\begin{array}{l}\text { Training and facilitation in the } \\
\text { field of animal husbandry }\end{array}$ & $\begin{array}{l}\text { Increase in livestock } \\
\text { yield every year. }\end{array}$ & $\begin{array}{l}\text { There was a decline in } \\
\text { the production of } \\
\text { Buffalo cattle by } 11.8 \\
8 \% \text {, and beef cattle of } \\
5.9 \% \text {. }\end{array}$ & $\begin{array}{l}\text { Growth and business } \\
\text { development of } \\
\text { livestock, in general, is } \\
\text { not an improvement. }\end{array}$ \\
\hline Overcoming job seekers & $\begin{array}{l}\text { The decreasing number } \\
\text { of job seekers. }\end{array}$ & $\begin{array}{l}\text { There was an increase in } \\
\text { job seekers by } 14 \% \text {. }\end{array}$ & $\begin{array}{l}\text { There are more job } \\
\text { seekers every year. }\end{array}$ \\
\hline
\end{tabular}




\section{HYPOTHESES DEVELOPMENT}

This study consists of three variables, namely civil servant competence, bureaucratic reform, and organizational performance. These three variables will be tested to see their effect between civil servant competence and bureaucratic reform on organizational performance in agencies in Cianjur. Based on the above reason, a better model is needed to describe the conditions of the three variables in Cianjur.

The basis for developing a model that describes the variables involved begins with the preparation of the following hypothesis:

Hypothesis 1: Civil servant competence has a positive effect on Organizational Performance in the Offices in Cianjur.

Civil servant competence variables are explained through various dimensions that have been used [13], namely: institutional arrangement, administration/ management arrangements, structuring human resources /civil servant, accountability/responsibility, public services.
Hypothesis 2: Bureaucratic Reform has a positive effect on Organizational Performance in Services in Cianjur.

The variables of bureaucratic reform are explained through various dimensions that have been used in ref [14], namely: task skills, task management skills, contingency management skills, job role environment skills, transfer skills.

Hypothesis 3: Civil servant Competence and Bureaucratic Reform have influencing the Organizational Performance in Offices in Cianjur.

Organizational performance variables are explained through various dimensions that have been used in ref [15], namely: organizational productivity, service quality, public responsiveness, public responsibility, and public accountability. Based on the three hypotheses above, the research paradigm model to be tested in Figure 1.

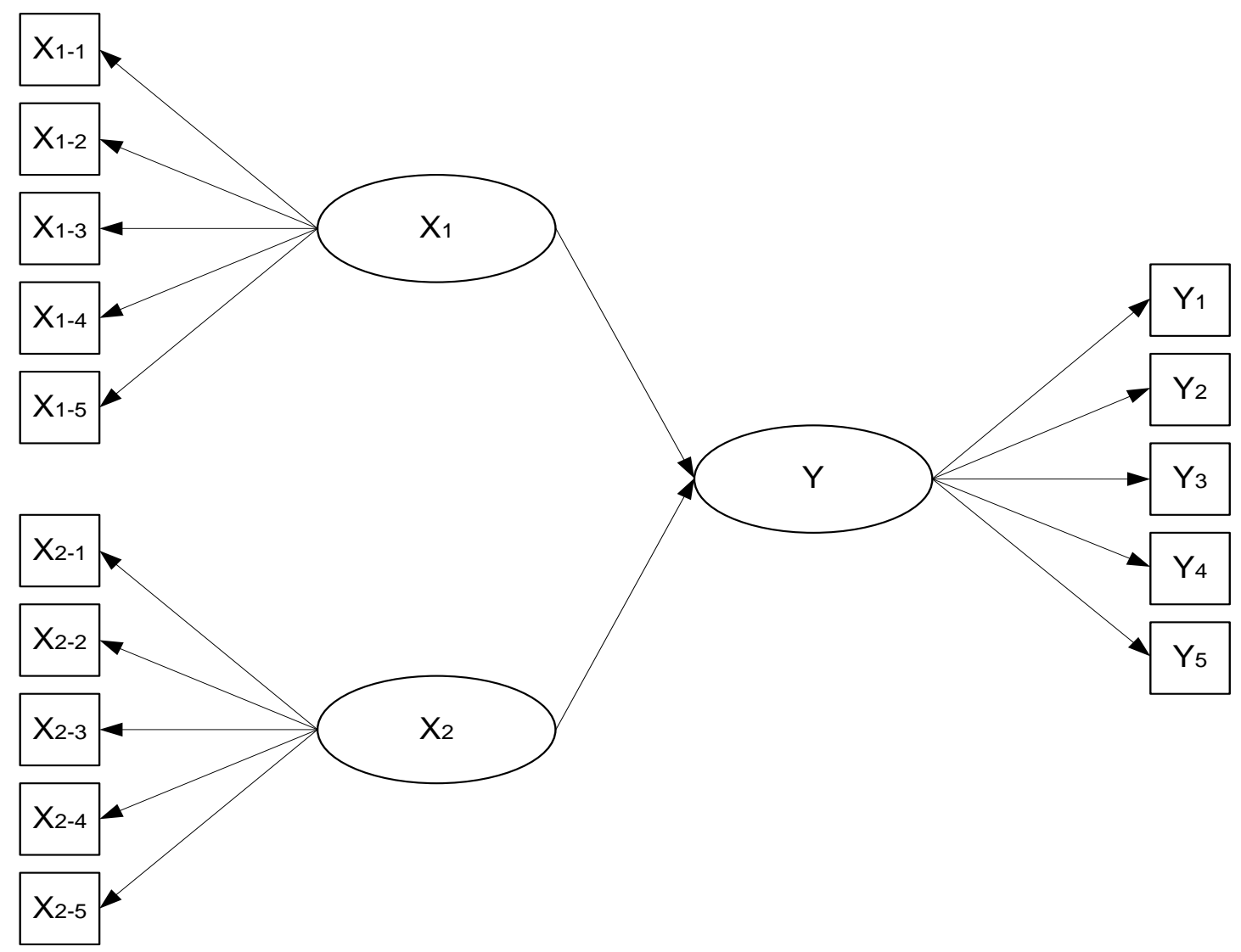

Figure 1. Structural Model of Civil servant Competence and Bureaucratic Reform on Organizational Performance 
Information:

$\mathrm{X}_{1}=$ Civil servant Competence

$\mathrm{X}_{1-1}=$ Task Skills

$\mathrm{X}_{1-2}=$ Task Management Skills

$\mathrm{X}_{1-3}=$ Contingency Management Skils

$\mathrm{X}_{1-4}=$ Job Role Environment Skills

$\mathrm{X}_{1-5}=$ Transfer Skills

$\mathrm{X}_{2}=$ Bureaucratic Reform

$\mathrm{X}_{2-1}=$ Institutional Arrangement

$\mathrm{X}_{2-2}=$ Management / Management

$\mathrm{X}_{2-3}=$ Human Resources / Civil servant Arrangement

$\mathrm{X}_{2-4}=$ Accountability (responsibility)

$\mathrm{X}_{2-5}=$ Public Service

$\mathrm{Y}=$ Organizational Performance

$\mathrm{Y}_{1}=$ Organizational Productivity

$\mathrm{Y}_{2}=$ Quality of Service

$\mathrm{Y}_{3}=$ Public Responsiveness

$\mathrm{Y}_{4}=$ Public Responsibility

$\mathrm{Y}_{5}=$ Public Accountability

\section{METHODOLOGY}

\subsection{Samples}

This research was conducted in all government offices in Cianjur, with 17 offices. Meanwhile, the population of official office employees is 298 people. For cases like this, sampling is carried out through Proportionate
Stratified Random Sampling as done in ref [16]. The calculation results (using Proportionate Stratified Random Sampling) obtained from the number of samples that are evenly distributed by the proportion of the number of employees in each service are 171 samples.

\subsection{Data Analysis}

This study used Structural Equation Mathematics (SEM) for data processing and data analysis. Excel and lisrel were the software used to process the data, such as converting ordinal data into intervals and processing interval data when using the SEM method.

\section{RESULT AND DISCUSSION}

The results of data collection obtained from the field after conducting the test show that the data is valid and reliable. Besides, testing of the transformed data shows that the data has passed the normality test, multicollinearity test, auto correlation test, heteroscedasticity test, and linearity test. After the data passes all the tests, it is continued at the model processing stage through SEM, which results in the following model values.

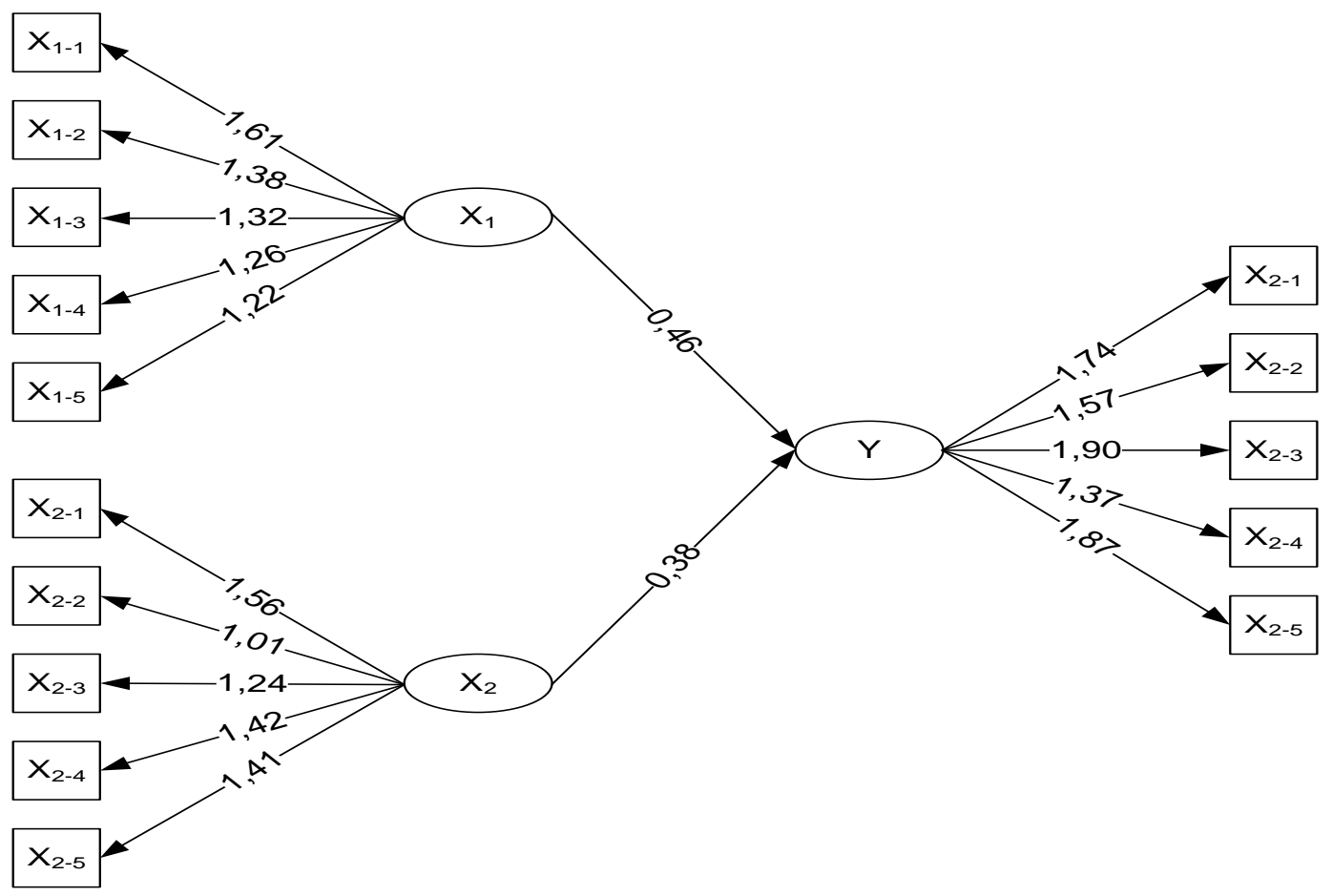

Figure 2. The Main Model Structure for Standardized Solution The Influence of Civil servant Competence and Bureaucratic Reform on Organizational Performance 


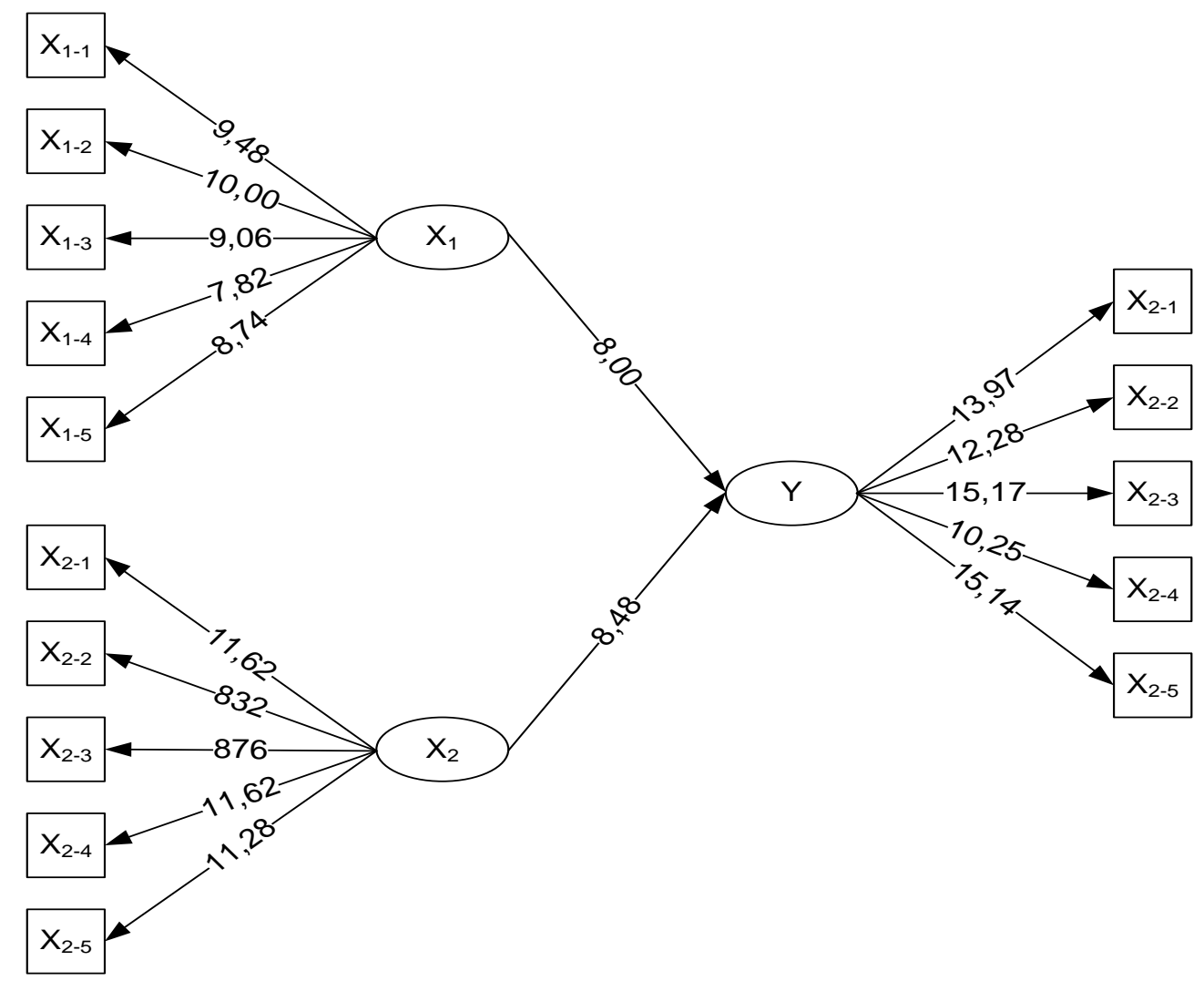

Figure 3. The Main Model Structure t-Value The Effect of Civil servant Competence and Bureaucratic Reform on Organizational Performance

Based on the structure of the model above, the structural equation model of Civil servant Competence $\left(\mathrm{X}_{1}\right)$ Bureaucratic Reform $\left(\mathrm{X}_{2}\right)$ on Organizational Performance $(\mathrm{Y})$ can be written in a structural equation, as follows:

$$
\begin{gathered}
Y=0.46 * X_{1}+0.38 * X_{2}, \text { Errorvar. }=0.63, \\
R^{2}=0.82
\end{gathered}
$$

The similarity gain from the test above, it can be analyzed that organizational performance will increase if the competence of the civil servant and bureaucratic reform is implemented in the offices in Cianjur. Simultaneously, civil servant competence and bureaucratic reform have a significant level of influence on organizational performance with an effective value of $82 \%$, so that the leadership's efforts to improve organizational performance in offices in Cianjur will have a significant impact if it focuses more on increasing apartment competence and bureaucratic reform. Meanwhile, if other factors are used, the level of change in organizational performance is not necessarily the impact of the civil servant competence and bureaucratic reform.

\section{CONCLUSIONS}

Based on the research results, it can be concluded that during the COVID-19 pandemic, for improving organizational performance, the leadership should be more focused on improving civil servant competence and bureaucratic reform. Because it has been confirmed from the hypothesis that the competence of the civil servant and bureaucratic reform can improve organizational performance in agencies in Cianjur. The level of influence given by civil servant competence and bureaucratic reform is also significant on organizational performance in agencies in Cianjur. 


\section{REFERENCES}

[1]. P. C. Silva, P. V. Batista, H. S. Lima, M. A. Alves, F. G. Guimarães, R. C. Silva. COVID-ABS: An agent-based model of COVID-19 epidemic to simulate health and economic effects of social distancing interventions. Chaos, Solitons \& Fractals, 139 (2020) 110088. DOI: https://doi.org/ 10.1016/j.chaos.2020.110088

[2] S. D. Halpern, R. D. Truog, F. G. Miller. Cognitive bias and public health policy during the COVID-19 pandemic. JAMA, 324 (4) (2020) 337338. DOI: https://doi.org/ 10.1001/jama.2020. 11623

[3] S. Wibawa, Reformasi Administrasi: Bunga Rampai Pemikiran Administrasi Publik. Yogyakarta: Gava Media, 2005.

[4] Z. Van der Wal. Being a Public Manager in Times of Crisis The Art of Managing Stakeholders, Political Masters, and Collaborative Networks. Public Administration Review. 80 (5) (2020) 1-12. DOI: https://doi.org/10.1111/puar.13245

[5] C. A. Dunlop, E. Ongaro, K. Baker, Researching COVID-19: A research agenda for public policy and administration scholars. Public Policy and Administration, 35 (4) (2020) 365-383. DOI: https://doi.org/10.1177/0952076720939631

[6]A. P. Hendroyuwono. Reformasi Birokrasi pada Organisasi Publik: Peran Kompleksitas Lingkungan Eksternal, Kapabilitas Strategis, Kapabilitas Perubahan dan Gaya Kepemimpinan dalam Mendorong Peningkatan Kinerja (Studi kasus reformasi birokrasi Ditjen Pajak Kementrian Keuangan Republik Indonesia). Dissertation. Management Science Doctoral Program, Strategic Specialization at the Postgraduate Program at the University of Indonesia, Jakarta, 2011.

[7] D. Cumming, S. Johan. Phasing out an inefficient venture capital tax credit. Journal of Industry, Competition and Trade, 10 (3-4) (2010) 227-252. DOI: https://doi.org/10.1007/s10842-0100080-3

[8] Mahmudi. Manajemen Kinerja Sektor Publik. Yogyakarta: Sekolah Tinggi Ilmu Manajemen YKPN, 2007.
[9] N. Z. Miah, L. Mia. Decentralization, accounting controls and performance of government organizations: a New Zealand empirical study. Financial Accountability \& Management, 12 (3) (1996) 173-190. DOI: https://doi.org//10.1111/j.14680408.1996.tb00421.x

[10] Z. Imatama. Pengaruh Kompetensi dan Motivasi terhadap Kinerja Pegawai pada PDAM Tirtanadi Cabang Padang Bulan Medan. Dissertation. Graduate School, University of North Sumatra, Medan, 2012.

[11] H. Zaim, M. F. Yaşar, Ö. F. Ünal. Analyzing the effects of individual competencies on performance: A field study in services industries in Turkey. Journal of Global Strategic Management, 7 (2) (2013) 67-77. DOI: https://doi.org/10.20460 /JGSM.2013715668

[12] A. Xu, L. Ye. Impacts of teachers' competency on job performance in research universities with industry characteristics: Taking academic atmosphere as moderator. Journal of Industrial Engineering and Management, 7(5) (2014) 12831292. DOI: https://doi.org/10.3926/jiem. 1261

[13] Moeheriono. Pengukuran Kinerja Berbasis Kompetensi. Jakarta: Ghalia Indonesia, 2009.

[14] Sedarmayanti. Reformasi Administrasi Publik, Reformasi Birokrasi dan Kepemimpinan Masa Depan (Mewujudka Pelayanan Prima dan Kepemerintahan yang Baik). Bandung: PT. Refika Aditama, 2009.

[15] Dwiyanto. Penilaian Kinerja Organisasi Pelayanan Publik. Yogyakarta: Faculty of Social and Political Sciences UGM, 2006.

[16] T. G. Bhagya. Pengaruh profesionalisme birokrasi dan pengembangan sumber daya manusia terhadap kinerja pegawai pada biro pelayanan sosial dasar Setda Jabar. Decision: Jurnal Administrasi Publik, 2 (1) (2020) 33-41. DOI: http://dx.doi.org/ 10.23969/decision.v2i1.2380 